\title{
"Urip Iku Mung Mampir Ngombe"; Konsep Kebahagiaan Masyarakat Miskin Pesisir Yogyakarta di Era Industrialisasi
}

\author{
"Urip Iku Mung Mampir Ngombe" (Life is only a while); \\ The Concept of Happiness of the Coastal Poor of Yogyakarta \\ in the Era of Industrialization
}

\author{
Casmini ${ }^{1}$, Fauzan Anwar Sandiah ${ }^{2}$ \\ ${ }^{1}$ Fakultas Dakwah dan Komunikasi, Universitas Islam Negeri Sunan Kalijaga \\ 2Program Doktoral Pascasarjana, Universitas Islam Negeri Sunan Kalijaga
}

\begin{abstract}
The study aimed to explore the concept of happiness of the coastal poor in Java. It was conducted using grounded approach through interviewing the poor in coastal D.I. Yogyakarta. Research subjects came from six different coastal areas; Parangtritis, Samas, Baru, Goa Cemara, Kuwaru, and Pandansari. This study used narrative content analysis for four aspects of the discourse that originated from 16 research subjects with the background of farmers, laborers, traders and fishermen; (1) a happy experience, (2) sad or risky experience, (3) sources of happiness, (4) individual interpretation of coastal environment conditions. The results showed that the concept of happiness was strongly associated with the fulfillment of physiological needs and social needs. "Urip iku mung mung mampir ngombe" (life is only a while) was the main narrative that described the concept of happiness as a subsistence strategy that became the foundation of the psychological welfare of coastal communities.
\end{abstract}

Keywords: coastal poor communities; concept happiness; the concept of psychological wellbeing

\begin{abstract}
Abstrak. Penelitian ini bertujuan mengeksplorasi konsep kebahagiaan dalam kesejahteraan psikologis masyarakat pesisir Jawa. Penelitian dilakukan dengan pendekatan grounded theory melalui wawancara terhadap masyarakat miskin di pesisir D.I. Yogyakarta. Subjek berasal dari enam lokasi pesisir pantai yang berbeda; Parangtritis, Samas, Baru, Goa Cemara, Kuwaru, dan Pandansari dengan latar belakang petani, buruh, pedagang dan nelayan. Penelitian ini menggunakan analisis konten naratif untuk empat aspek wacana yang berasal 16 subjek penelitian (1) pengalaman bahagia, (2) pengalaman sedih atau berisiko, (3) sumbersumber kebahagiaan, (4) interpretasi individu akan kondisi lingkungan pesisir. Hasil penelitian menunjukkan bahwa konsep kebahagiaan secara kuat berhubungan dengan terpenuhinya kebutuhan fisiologis dan kebutuhan sosial. "Urip iku mung mampir ngombe" (hidup itu hanya sekadar mampir minum) merupakan narasi utama yang menggambarkan konsep kebahagiaan sebagai strategi hidup subsistent yang menjadi landasan kesejahteraan psikologis masyarakat pesisir.
\end{abstract}

Kata kunci: konsep kebahagiaan; kesejahteraan psikologis; masyarakat miskin pesisir

\footnotetext{
${ }^{1}$ Korespondensi mengenai artikel ini dapat melalui: casmini@uin-suka.ac.id
} 
Kajian mengenai konsep kebahagiaan dapat ditelusuri hingga ke teks-teks filsasat Yunani (White, 2006), juga merupakan salah satu implikasi dari kajian atas konsep kualitas hidup nonekonomi (Quality of Life Studies) pada tahun 1960an (Diener \& Seligman, 2004; Kesebir \& Diener, 2008; Maggino, 2015). Penelitian mengenai konsep kebahagiaan sebagaimana diungkapkan oleh Maggino (2015) berasal dari tradisi gerakan indikator sosial yang bertujuan untuk menemukan faktor-faktor non-ekonomi dari kesejahteraan manusia/masyarakat. Agenda riset mengenai kebahagiaan telah berkembang cukup luas dan memberikan kontribusi bagi pembahasan-pembahasan konseptual, metodologis, hingga ke praktis. Maggino mencatat bahwa perkembangan itu telah membawa konsep kebahagiaan dan kesejahteraan subjektif sebagai topik inklusif yang berlaku untuk semua jenis kebudayaan, kelompok mayoritas ataupun minoritas (subgroups), dan kelas sosial yang lemah seperti petani tanpa alat produksi (Davey, Chen, \& Lau, 2009).

Penelitian mengenai konsep kebahagiaan telah diterapkan untuk beragam fenomena sosial, termasuk dalam dimensi dan aspek kebahagiaan pada masyarakat urban dengan contoh kasus pada komunitas di Rusunawa (Adams, 1992; Bruscaglioni, Cellini, \& Saracino, 2015; Thériault, Leclerc, Wisniewski, Chouinard, \& Martin 2010), dan masyarakat pinggiran (Berry \& Okulicz-Kozaryn, 2011; Knight, \& Gunatilaka, 2010a; Knight, \& Gunatilaka, 2010b; Liltsi, Michailidis, \& Partalidou, 2014; Michalos, 1983). Dua karakter masyarakat atau komunitas ini memungkinkan penemuan baru mengenai konsep kebahagiaan. Hal ini telah membuat kajian mengenai kebahagiaan demikian kompleks dan menantang. Kajian mengenai kebahagiaan telah melibatkan aspek sosial lainnya seperti kebudayaan, kebijakan publik, dan kelas sosial.

Penelitian ini secara kritis memanfaatkan beberapa temuan penting dalam kajian konsep kebahagiaan terutama yang berkaitan dengan kebahagiaan masyarakat pinggiran (rural). Kemiskinan memiliki pengaruh yang rendah terhadap pembentukan kebahagiaan masyarakat pinggiran (Amato \& Zuo, 1992) serta pada tuna wisma (Panadero, Guillén, \& Vázquez, 2015). Lingkungan pinggiran, pesisir, ataupun pedesaan memiliki lebih sedikit tekanan psikologis pada manusia daripada lingkungan perkotaan. Faktor-faktor yang turut memengaruhi kebahagiaan diantaranya mencakup aspek-aspek sosial, lingkungan fisik, dan kebijakan publik. Amato \& Zuo (1992) juga menambahkan bahwa bagi masyarakat yang hidup di kawasan pinggiran, jejaring sosial sangat penting untuk membentuk kebahagiaan. Relasi sosial yang kuat akan memengaruhi kebahagiaan masyarakat pinggiran. Dalam konteks masyarakat pesisir, konsep kebahagiaan sangat bergantung pada relasi-relasi sosial yang dibentuk dan dipertahankan.

Amato \& Zuo (1992) juga mencatat bahwa aspek ekonomi seperti kemiskinan akan terus memengaruhi penjelasan mengenai konsep kebahagiaan bagi masyarakat pinggiran. Salah-satu alasannya karena kemiskinan merupakan realitas sosial yang memberi pengaruh terhadap stigma dan stereotip sehingga menghasilkan perlakuan sosial berbedabeda. Pembentukan konsep-konsep kebahagiaan pada akhirnya secara relatif dipengaruhi oleh konstruksi antara kemiskinan dan kesejahteraan. Stigma dan stereotip semacam itu cenderung lebih berpengaruh secara sosial bagi masyarakat pinggiran daripada masyarakat perkotaan. 
Dengan demikian menjadi sangat penting untuk menjaga konteks pengembangan teoritis konsep kebahagiaan dengan mempertimbangkan kehadiran aspek ekonomi secara tidak langsung. Oleh karena itu, penelitian mengenai konsep kebahagiaan penting untuk mencakup konstruk-konstruk hasil konsekuensi aspek ekonomi seperti kelas sosial dan struktur masyarakat.

Penelitian mengenai kebahagiaan manusia atau komunitas masyarakat pada umumnya diteliti melalui dua kategori variabel yakni variabel mikro dan variabel sosial ekonomi (makro). Dua kategori variabel itu juga menjadi tanda berakhirnya asumsi dasar bahwa kesejahteraan ekonomi memberi pengaruh signifikan terhadap tingkat kebahagiaan (Diener, Diener \& Tamir, 2004; Kesebir \& Diener, 2008; Landiyanto, Puspitasari \& Irianti, 2011; Ribeiro \& Marinho, 2016; Seligman, 2002; Sohn, 2010). Perdebatan awal mengenai kebahagiaan berasal dari bagaimana kebahagiaan didefinisikan dan dipahami. Dua filsuf klasik, G.W. Hegel dan Karl Marx memiliki pandangan yang berbeda mengenai kebahagiaan. Hegel menekankan bahwa kebahagiaan pada dasarnya merupakan konstruksi internal, bagian dari produk kognitif manusia. Sedangkan Karl Marx menyatakan bahwa kebahagiaan merupakan konsekuensi dari praktik kerja sosial, bersifat material dan historis (Freund, 1985). Dua cara pandang fundamental ini memberi implikasi penting mengenai penggunaan terminologi kebahagiaan dalam riset-riset berikutnya. Termasuk di dalamnya ialah terdapatnya beragam konsep untuk meneliti kebahagiaan misalnya konsep kesejahtaraan psikologis (psychological well-being).

Implikasi pertama adalah kebahagiaan tidak lagi dipandang sekadar hasil dari emosi temporer ataupun bersifat jangka panjang. Kebahagiaan tidak sekadar produk kognitif cara berpikir rasional, melainkan sebuah konsekuensi dari proses interaksi antara struktur dan fungsi otak (Matsunaga et al., 2016). Riset semacam ini hendak memperlihatkan bahwa kebahagiaan merupakan proses biologis yang melibatkan interaksi organ internal manusia. Kebahagiaan dengan demikian tidak selalu dapat dimaknai sebagai manifestasi rasionalitas atau intelektualitas dan batiniah, melainkan konsekuensi dari interaksi antara aspek psikis dan aspek fisik. Dengan demikian terminologi kesejahteraan psikologis tidak saja berarti wujud psikis melainkan hasil dari mekanisme fisik manusia.

Implikasi kedua adalah tendensi riset kebahagiaan dan kesejahteraan psikologis dalam beberapa tahun belakangan ini dilekatkan dengan variabel makro yang beririsan langsung dengan aspek-aspek sosial, ekonomi, teknologi dan politik seperti dialami oleh kelas migran urban baru (Wei \& Gao, 2017). Hal ini menunjukkan bahwa eksplorasi mengenai kebahagiaan akan memberikan kontribusi menarik jika dilakukan dengan melihat kaitan antara konteks-konteks eksternal (karakter geografis tempat komunitas hidup, kebijakan ekonomi-politik, dan perkembangan teknologi) dan konteks internal subjek (kesejahteraan psikologis).

Implikasi ketiga, terminologi kebahagiaan juga mulai digunakan untuk kelompok-kelompok masyarakat minoritas seperti komunitas miskin perkotaan (Purnamasari, Setyono \& Dayana, 2016) sebagai "subjek pinggiran". Kendati demikian, jenis riset tentang kesejahteraan psikologis komunitas-komunitas pinggiran di area urban tidak banyak dilakukan. Penyebabnya antara lain karena terminologi kebahagiaan atau kesejahteraan psikologis cenderung dilihat sebagai 
hasil absolut dari pengalaman hidup dan refleksi internal individu terhadap dunia. Padahal beberapa konteks budaya dan ekonomi-politik juga memiliki pengaruh relatif signifikan terhadap perubahanperubahan pemaknaan konsep kebahagiaan atau kesejahteraan psikologis.

Ketiga implikasi riset mengenai kesejahteraan psikologis di atas sepenuhnya memperlihatkan otonomitas subjek sebagai faktor utama pembentuk kebahagiaan. Faktor transformasi atau perubahanperubahan ekonomi-politik belum banyak diperhatikan sebagai medan awal untuk menggali kemungkinan soal pemaknaan aktual kesejahteraan psikologis. Transformasi di area pinggiran urban seperti daerah pesisir di provinsi D.I. Yogyakarta yang berubah dari arena ekonomi informal menjadi area industri tentu saja secara relatif mengubah respon temporer subjek terhadap kesejahteraan psikologis keseharian (everyday psychological wellbeing). Beberapa riset mengenai kebahagiaan difokuskan untuk melihat kebahagiaan yang bersifat aktual-segera dan temporal (Stets \& Tettrevik, 2016).

Kajian mengenai konsep-konsep kebahagiaan ataupun kesejahteraan psikologis masyarakat daerah pesisir tidak mendapatkan porsi secara memadai. Masyarakat pesisir mengalami beberapa transformasi akibat industri pariwisata dan kebijakan pemanfaatan lahan. Perubahan-perubahan tersebut secara relatif memengaruhi variabel-variabel yang selama ini dianggap punya peran dalam pembentukan kebahagiaan semacam relasi sosial, simbol budaya, dan aktivitas ekonomi. Penelitian ini mengadaptasi asumsi dasar bahwa kesejahteraan psikologis masyarakat pesisir era industrial punya konsep khas yang membentuk deskripsi atas kebahagiaan dan kesejahteraan psikologis.

\section{Metode}

Penelitian ini menggunakan metode kualitatif dengan pendekatan grounded theory, dengan tiga pertimbangan pokok. Pertama, metode grounded theory memiliki kapasitas untuk mengapresiasi perspektif orang-orang dari latar belakang budaya yang khas seperti dalam riset-riset terhadap "Orang Asli" (Rabahi, Yusof \& Awang, 2015). Kedua, metode grounded theory banyak digunakan untuk menangkap variatifnya perspektif mengenai kebahagiaan dan memiliki sensitifitas terhadap berbagai variabel kebahagiaan seperti modal sosial, budaya, relasi sosial dan gender (Eriksson \& Emmelin, 2013; Paralkar, Cloutier, Nautiyal dan Mitra, 2017). Ketiga, metode grounded theory banyak digunakan untuk menggali pemahaman natural manusia secara apresiatif dan membebaskan peneliti dari bias-bias budaya (Balthip \& Purnell, 2014; Casmini, 2016).

Responden diambil berdasarkan karakteristik aktivitas sosial-ekonomi pada masyarakat pesisir yang berkategorikan pertama; kelompok masyarakat turun temurun hidup di kawasan pesisir, dan merupakan bagian dari perpindahan yang secara umum berlaku di seluruh wilayah pesisir Indonesia. Kedua, masyarakat pesisir merupakan komunitas perantau yang hidup dengan mendiami area pesisir sebagai cara bertahan hidup dan proses pengembangan kebudayaan baru.

Penelitian ini difokuskan pada enam area pesisir yang menjadi lokasi penerapan kebijakan industri pariwisata D.I. Yogyakarta, yakni: Pantai Parangtritis, Pantai Samas, Pantai Baru, Pantai Goa Cemara, Pantai Kuwaru, dan Pantai Pandansari. Tabel 1. memaparkan karakteristik responden yang terlibat. 
Tabel 1.

Karakteristik Reponden

\begin{tabular}{ccllc}
\hline No Subjek & Usia & Gender & \multicolumn{1}{c}{ Pekerjaan } & Lokasi Pantai \\
\hline 1 & 59 & Perempuan & Jualan di warung & Parangtritis \\
2 & 50 & Perempuan & Jualan di warung & Parangtritis \\
3 & 40 & Laki-Laki & Jualan di warung dan tukang parkir & Parangtritis \\
4 & 60 & Perempuan & Jualan di warung dan tukang parkir & Samas \\
5 & 57 & Perempuan & Jualan di warung & Samas \\
6 & 53 & Perempuan & Jualan di warung & Samas \\
7 & 38 & Perempuan & Petani dan Warung & Baru \\
8 & 45 & Perempuan & Ibu Rumah Tangga & Baru \\
9 & 58 & Laki-Laki & Warung, Jual Ikan, Buruh, Serabutan, & Baru \\
10 & 60 & Laki-Laki & Petani, buruh pabrik & Baru \\
11 & 57 & Perempuan & Jualan di warung & Baru \\
12 & 45 & Perempuan & Warung, Petani, Ternak Sapi & Baru \\
13 & 50 & Laki-Laki & Pembuat Bata & Baru \\
14 & 70 & Perempuan & Pedagang & Pantai Goa Cemara \\
15 & 60 & Perempuan & Jualan di warung & Kuwaru \\
16 & 75 & Perempuan & Jualan di warung & Pandansari \\
\hline
\end{tabular}

Alur metode grounded theory yang digunakan dalam penelitian terdiri atas enam langkah. Pertama dengan melakukan pengumpulan data. Metode pengumpulan data yang digunakan adalah wawancara mendalam dan observasi konteks geografis responden tinggal. Kedua, kodifikasi dan kategorisasi menggunakan model kode deskriptif (descriptive code) yang memberi afirmasi terhadap topik-topik tertentu yang muncul. Ketiga, memos atau pencatatan dilakukan dengan menggunakan perpaduan antara penulisan deskriptif dan narasi dalam tabel. Ketiga, klasifikasi, yaitu dengan memberikan penandapenanda pada data. Keempat, memformulasikan kerangka teoretis yang dianggap mampu menjelaskan data. Kelima, melibatkan literatur untuk memahami apakah kerangka teoretis yang dibangun mampu direfleksikan dengan temuantemuan sebelumnya.

Partisipan mendapat empat pertanyaan pokok terkait dengan : (1) pengalaman bahagia, (2) pengalaman buruk atau sedih yang pernah dialami oleh responden, (3) sumber kebahagiaan yang dipahami oleh responden, (4) tantangan industrial yang dialami oleh responden di area pesisir.

\section{Hasil}

Rangkuman hasil wawancara dapat dilihat pada Tabel 2. Dari data tersebut, muncul dua tema besar dari penelitian ini, yaitu 'Urip mung Mampir Ngombe' dan 'dekati yang baik-baik, jauhi yang buruk-buruk'. 
Tabel 2.

Rangkuman Hasil Wawancara

\begin{tabular}{|c|c|c|c|}
\hline Pengalaman Bahagia & $\begin{array}{l}\text { Pengalaman Sedih/ } \\
\text { buruk/Berisiko }\end{array}$ & $\begin{array}{c}\text { Sumber } \\
\text { Kebahagiaan }\end{array}$ & $\begin{array}{c}\text { Tantangan Industri } \\
\text { Pariwisata }\end{array}$ \\
\hline $\begin{array}{l}\text { 1. Tercukupinya } \\
\text { kebutuhan materi }\end{array}$ & $\begin{array}{l}\text { 1. Musibah (warung } \\
\text { kebakaran) }\end{array}$ & $\begin{array}{l}\text { 1. Timbal balik } \\
\text { dari perbuatan }\end{array}$ & $\begin{array}{l}\text { 1. Rusaknya hutan } \\
\text { cemara }\end{array}$ \\
\hline $\begin{array}{l}\text { 2. Keluarga yang } \\
\text { utuh }\end{array}$ & $\begin{array}{l}\text { 2. Kematian pasangan hi- } \\
\text { dup, keluarga, atau anak }\end{array}$ & $\begin{array}{l}\text { baik } \\
\text { 2. Nasib atau }\end{array}$ & $\begin{array}{l}\text { 2. Belum siap } \\
\text { menghadapi }\end{array}$ \\
\hline 3. Kesehatan keluarga & 3. Per & tak & aktivitas \\
\hline $\begin{array}{l}\text { 4. Hubungan baik } \\
\text { dengan tetangga }\end{array}$ & $\begin{array}{l}\text { 4. Jauh dari anak-anak } \\
\text { 5. Dampak-dampak }\end{array}$ & $\begin{array}{l}\text { 3. Disebabkan } \\
\text { oleh usaha dan }\end{array}$ & $\begin{array}{l}\text { ekonomi } \\
\text { 3. Kehilangan aktivitas }\end{array}$ \\
\hline 5. Rumah yang bagus & lingkungan (abrasi) & ikhtiar & ekonomi tradisional \\
\hline 6. Ekonomi lancar & terhadap pemukiman & & \\
\hline 7. Punya waktu luang & 6. Gagal pa & & m dan \\
\hline $\begin{array}{l}\text { 8. Perlakuan adil dari } \\
\text { masyarakat }\end{array}$ & $\begin{array}{l}\text { 7. Kelaparan } \\
\text { 8. Ditipu }\end{array}$ & & $\begin{array}{l}\text { kerajinan daun } \\
\text { pandan) }\end{array}$ \\
\hline $\begin{array}{l}\text { 9. Berkaitan dengan } \\
\text { keagamaan }\end{array}$ & $\begin{array}{l}\text { 9. Menjadi beban bagi orang } \\
\text { lain }\end{array}$ & & $\begin{array}{l}\text { 4. Sampah yang } \\
\text { merusak ekosistem }\end{array}$ \\
\hline 10. Tidak ada bencana & 10. Hutang yang menumpu & & pesisir pantai \\
\hline
\end{tabular}

Urip mung mampir ngombe

Konsep kebahagiaan yang ditemukan dalam penelitian ini ditandai oleh tujuantujuan spesifik yang diungkapkan dengan "hidup itu sekadar berhenti sejenak untuk minum" (urip iku mung mampir ngombe). Kebahagiaan dalam hal ini mensyaratkan jaminan bahwa selama kebutuhan hidup (fisiologis; makan dan minum, dan relasi sosial) masih dapat terpenuhi secara cukup (subsistent) maka tidak ada yang perlu dikhawatirkan, karena ada faktor spiritualitas yang tidak dapat dijangkau oleh akal manusia. Sebanyak 16 responden penelitian ini mengungkapkan bahwa kebahagiaan dan kesejahteraan psikologis didorong oleh tiga motif yakni, "terhindarnya diri dari risiko" (S-1; S-12; S-15; S-16), "keadaan tanpa risiko tetapi berhasil" (S-1; S-5; S-8) dan "tercukupinya kebutuhan [fisiologis dan sosial]" (S-3; S-9; S-13) serta bentuk kepasrahan kepada Tuhan (S-1; S-5; S-12).

Konsep kebahagiaan berasal dari sumber-sumber yang beragam, seperti petuah, cerita, dan anekdot-anekdot, pengalaman individual, pengalaman batiniah, dan pengalaman sosial sebagaimana budaya yang turun-temurun. Salah satu cerita subjek sebagai berikut.

"Hidupku mengejar uang, punya kendaraan bagus, atau kepemilikan tanah tidak menjamin hidupku bahagia. Contoh yang saya amati, orang-orang yang sejahtera secara materi tidak selalu hidup beruntung. Ada orang yang berkecukupan tapi bernasib sial dengan ditinggal hidup sendirian oleh anak-anak di masa tua, ada juga yang ditinggal pergi oleh istri. Belajar untuk kebahagiaan sangatlah sederhana, jika seseorang bermimpi hidup sukses terlalu tinggi tanpa dilandasi oleh sikap bersyukur pada Tuhan, maka itu akan berdampak buruk" (S13, S10).

Masyarakat pesisir Yogyakarta mempertahankan konsep kebahagiaan (hidup sekadar mampir minum) untuk menghambat proses reduksi yang dimungkinkan 
oleh transformasi desa atau kampung dari industri pariwisata kapitalistik. Beberapa bentuk konsep kebahagiaan yang secara spesifik dibentuk menjadi gagasangagasan dapat dilihat pada Gambar 1.

Masyarakat pesisir juga meletakkan makna kolektif-sosial untuk menginterpretasi konsep kebahagiaan melalui pemahaman bahwa hubungan sosial yang baik dapat membawa manfaat bagi kesejahteraan psikologis. Seseorang harus sebisa mungkin menghindari kemungkinan kerugian sosial yang dapat diterimanya karena tidak terlibat dalam relasi sosial secara sehat, maka "hidup harus baik-baik dengan tetangga, kadang mereka butuh kita bantu, nanti kita juga butuh dibantu" (S-1), "kadang kita mesti memberi pada orang lain ketika mereka susah, kita musti membayangkan jika suatu hari nanti kita berada pada posisi sulit maka harus bisa membantu orang dekat" (S-11) serta "hidup bisa bolak-balik, kadang kita menolong, kadang kita ditolong" (S-14).

Bagi masyarakat miskin di pesisir, kolektivitas dan relasi sosial akan meningkatkan jaminan hidup subsistent. Seseorang akan memperoleh pertolongan orang lain jika dirinya sendiri pernah berbuat hal serupa.

"Kalau ada tenaga ya bantu tenaga, bisa juga doa yang penting membantu orang lain yang lagi sulit" (S-13),

"Saya pernah membantu orang, insyaAllah kalau kita lagi sulit akan ada pertolongan" (S-7).
Masyarakat pesisir memiliki relasi sosial yang sangat padat. Setiap orang di area pesisir terlibat dalam kontak sosial yang kuat dengan tetangganya. Hal ini juga membenarkan klaim bahwa masyarakat pesisir memiliki pola sosial tolongmenolong dengan intensitas relatif lebih banyak daripada masyarakat perkotaan. Masyarakat pesisir memperoleh kebahagiaan melalui interaksi-interaksi interpersonal, sebagaimana petikan wawancara bahwa "saya senang kalau bisa membantu tetangga, itu artinya kita bermanfaat bagi orang lain" (S-10).

Selain itu, dukungan sosial memiliki fungsi penting bagi masyarakat pesisir, yakni dengan memberikan peluang bagi masyarakat miskin pesisir terhindar dari konsekuensi negatif kemiskinan. Sebagaimana petikan wawancara:

“Pesisir jadi tempat cari uang, kerja di sini musti kenal baik dengan yang lain supaya kalau ada apa-apa kita bisa ditolong atau dibantu" (S-4).

"Kalau punya usaha warung musti bagi-bagi sama teman yang juga punya warung. Kalau kita sepi pelanggan yang mampir warung, nanti ada teman yang mengarahkan pengunjung supaya jajan ke sini" (S-16).

"Di pesisir gampang cari duit, asal sama teman lain saling bantu" (S-4, S16, S-14).

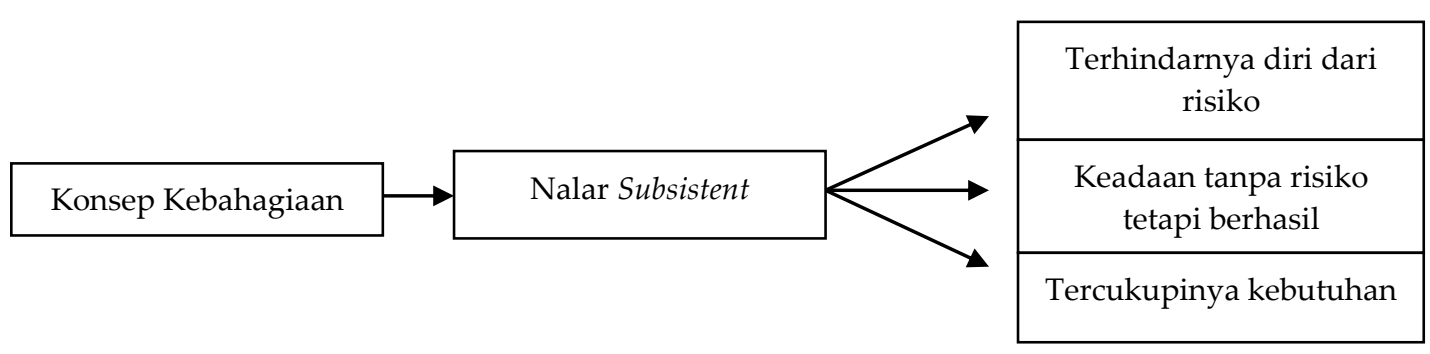

Gambar 1.

Konsep kebahagiaan dan nalar subsistent 
Skema pembentukan konsep kebahagiaan ini tentu saja berasal dari pengalaman yang bersifat historis. Pengalaman sedih semacam gagal panen, ditimpa bencana, atau kerugian dalam perniagaan tidak terakumulasi, tetapi membentuk pemahaman mengenai hidup subsistent. Pengalaman sedih membuat individuindividu ini percaya bahwa yang manusia butuhkan hanyalah menghindari sebanyak mungkin malapateka, dan mempererat silaturahmi sosial sehingga memungkinkan kebahagiaan muncul. Individuindividu ini sangat menghargai keadaan atau kondisi yang memungkinkan malapeteka bisa dihindari seperti kesehatan dan kompetensi. Dilema kebahagiaan muncul dari kesadaran bahwa keniscayaan malapetaka dapat dihindari asalkan "eling lan waspada". Skema mengenai pembentukan konsep kebahagiaan yang menjadi dasar kesejahteraan psikologis dapat diperhatikan melalui gambar 2 .

Garis tegas pembentuk konsep kebahagiaan berasal dari pemahaman mengenai dilema kebahagiaan. Kebahagiaan sebagai pengalaman, relatif minim dalam ingatan individu-individu ini. Responden kesulitan mengumpulkan dan mengingat pengalaman-pengalaman bahagia yang pernah dicapai. Ketika diberi pertanyaan mengenai apa saja pengalaman bahagia yang telah mereka alami, kecenderungan repetitif tidak terelakkan. Titik jenuh dari data mengenai kebahagiaan memunculkan dugaan bahwa pengalaman bahagia tidak sedemikian langsung dalam membentuk konsep kebahagiaan. "Urip iku mung mampir ngombe" tidak saja memperlihatkan bahwa dunia ini sebagai realitas adalah tempat persinggahan, tetapi juga menyatakan bahwa apapun yang terjadi "kulo nderek mawon." Baik pengalaman bahagia atau pengalaman sedih, "saya ikut saja."
Pengalaman bahagia dan pengalaman sedih berhubungan dengan konsep kebahagiaan melalui garis putus-putus yang berarti relasinya bisa langsung atau tidak langsung. Pengalaman bahagia dan pengalaman sedih memang punya andil dalam pembentukan konsep kebahagiaan. Kendati demikian, tidak dapat juga disebut menjadi landasan utama konsep kebahagiaan. Kesimpulan bahwa "urip iku mung mampir ngombe" tidak mensyaratkan terjadinya pengalaman bahagia atau sedih terlebih dahulu. Tetapi, justru setelah terjadinya pengalaman bahagia atau sedih, "urip iku mung mampir ngombe" sudah siap sebagai tameng ugahari (pelindung kesederhanaan). Hidup sederhana meyakini bahwa kehidupan telah diatur dan ditentukan, manusia cukup menjalani dan menerima peristiwa, baik atau buruk (S-4, S-10, S-14, S-16).

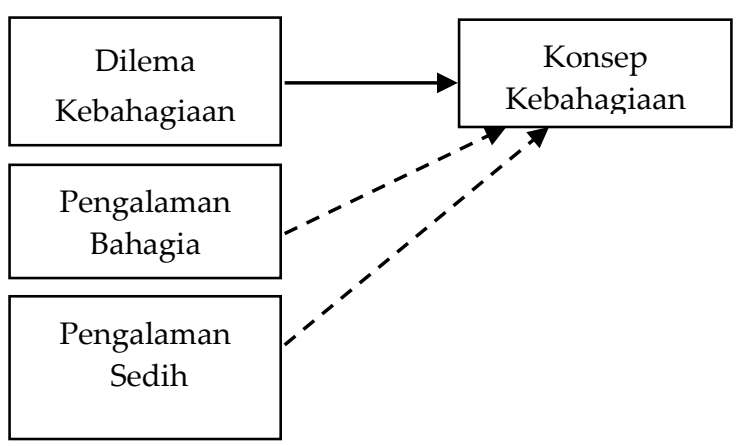

Gambar 2. Skema pembentukan konsep kebahagiaan

Dilema kebahagiaan merupakan kondisi di mana individu merasa bahwa hidup hanya sekadar persinggahan sekaligus penentuan, yang tidak dapat dipilih salah-satu. Dilema kebahagiaan bukan merupakan dilema atas pengalaman bahagia, tetapi merupakan strategi hidup bahagia dengan mengurangi risikorisiko baru yang belum tentu mampu ditangani berdasarkan pengalaman ataupun yang tidak perlu diambil karena harus menyelesaikan risiko hidup lainnya. Dilema ini tersusun atas prinsip 
mendahulukan selamat sebagaimana ungkapan sebagai berikut.

"Kadang ada yang nawarin modal tambahan, tapi saya tidak ambil. Lagian saya sudah tua, yang penting bisa makan atau ngasih jajan cucu udah cukup. Kalau modal itu saya ambil, terus nanti nggak bisa dibalikin ya saya jadi susah. Kasian anak sama cucu" (S-14 S-13).

"Saya kerja secukupnya aja, santai, tidak terburu-buru. Saya nggak pernah ngejar target bikin batu bata berapa banyak. Nanti kalau uang udah mulai berkurang, baru saya bikin bata lagi. Gitu aja. Mana yang kita butuh itu yang kita dahuluin. Kalau butuh bikin rumah buat anak ya nanti baru cari duitnya"(S-13).

Prinsip mendahulukan selamat merujuk pada penentuan skala prioritas kebutuhan dan bersikap pragmatis pada pilihanpilihan hidup. Sikap praktis yang diambil bukan bermakna keengganan mengambil peluang untuk berkompetisi, melainkan mengantisipasi risiko baru yang dianggap tidak patut diambil.

Kehidupan individu di area pesisir yang begitu dinamis akibat pengaturan sosial, dan intervensi-intervensi eksternal, membuat mereka harus mempunyai pegangan tentang "cara selamat" yang paling memungkinkan menurut pengalaman sebelumnya. Misalnya individu yang bekerja sebagai petani, menerapkan prinsip "dahulukan selamat" ini dengan mengurangi penggunaan teknologi yang tidak dia kuasai. S-10 mengungkapkan, "daripada aku pake tapi gagal, mendingan pake yang pasti-pasti saja" atau ungkapan S-9 "daripada beli alat-alat baru, mendingan uangnya dipake bayar sekolah anak". Petani seperti S-9 bukan menolak kemungkinan bahwa panennya akan melimpah misalnya dengan menggunakan bibit atau pupuk jenis baru, melainkan merasa tidak perlu mengambil risiko baru yang belum tentu mampu diatasi.

Pedagang-pedagang kecil di area pesisir lebih memilih menjual minuman daripada harus mengambil kesempatan berbisnis rumah makan. Alasan bukan disebabkan modal kapital, namun meyakini relasi sosial yang memungkinkannya memperoleh kesempatan mengembangkan bisnis serta mempertimbangkan risiko seperti kerugian, persaingan berdagang ataupun bertani dengan tetangga, dan kesan ambisius sebagai konsekuensi risiko sosial, ekonomi, politik, hingga budaya.

Dekati yang baik-baik, jauhi yang buruk-buruk Risiko adalah kekhawatiran utama yang membuat masyarakat miskin di pesisir Yogyakarta memilih hidup subsistent. Di pesisir pantai Baru, beberapa individu yang terdiri atas tukang, buruh, dan petani, mempertahankan hidup subsistent dengan menjaga berlangsungnya sikap tolong-menolong dan kedermawanan. Kekhawatiran tunggal yang selalu menjadi ancaman bagi kebahagiaan maupun kesejahteraan psikologis adalah ketidakmampuan menyediakan kebutuhan pokok. Kekhawatiran klasik semacam ini tidak dapat ditinggalkan. Dalam analisaanalisa kebahagiaan dan kesejahteraan yang lazim diungkap, tampaknya mengandung bias besar. Riset-riset itu secara berlebihan menempatkan bahwa aktualisasi sebagai persoalan utama dari kebahagiaan dan kesejahteraan psikologis. Hal ini bertolak belakang dengan masyarakat pesisir yang dijadikan responden. Pada umumnya mereka tak tertarik membahas persoalan "aktualisasi diri."

"Dekati yang baik-baik, jauhi yang buruk-buruk" (adalah argumentasi penting mengenai konsep kebahagiaan. "Dekati yang baik-baik" berarti memper- 
oleh, mendapatkan, atau menemukan kebaikan. Masyarakat pesisir percaya bahwa tuhan selalu menyediakan "yang baik-baik" bagi mereka. Berkaitan dengan konsep "Tuhan", masyarakat pesisir juga memiliki kepercayaan tertentu terhadap kekuatan-kekuatan supranatural. Seseorang tidak selalu memperoleh "yang baik-baik" secara kebetulan. Kekuatan supranatural seperti tuhan, malaikat, jin, arwah leluhur, atau takdir dan nasib juga punya peran bagi keberuntungan. Kendati demikian, peran dimensi mistisisme dalam masyarakat pesisir Yogyakarta secara relatif memiliki akar dengan kehidupan empiris. Nasib dan takdir baik bagi mereka juga berasal dari konsekuensi perbuatan sehari-hari.

Implikasi-implikasi sosial dan kebudayaan dari argumentasi-argumentasi konsep kebahagiaan ini secara relatif menjadi wawasan bagi makna kesejahteraan psikologis. Salah-satu bukti misalnya bahwa argumentasi-argumentasi ini telah mendorong terjadinya perilaku saling tolong-menolong dan kesediaan terlibat dalam kerja-kerja sosial. Termasuk di dalamnya ialah etika-etika yang mereka bentuk dalam aktivitas ekonomi di area pesisir melalui pembagian sumber pemerolehan rezeki secara sengaja. Kesejahteraan psikologis secara kolektif diperoleh melalui implikasi sosial dan kebudayaan semacam ini. Oleh karena itu, empat argumentasi yang diajukan dalam konsep kebahagiaan merupakan gambaran mengenai kesejahteraan psikologis.

\section{Diskusi}

Temuan kebahagiaan dalam pandangan masyarakat pesisir Jawa yang berorientasi pada relasi sosial untuk kebahagiaan personal menguatkan temuan penelitian Casmini (2016), meski dalam varian masyarakat Jawa yang lebih spesifik. Kebahagiaan masyarakat miskin pesisir Jawa bukan berasal dari kehidupan secara fisik-personal, namun komponen sosial menjadi dasar kebahagiaan. Temuan ini senada dengan yang dikatakan oleh Diener dan Seligman (2004) yang menyatakan bahwa kebahagiaan merupakan kesenangan yang memiliki komponen indrawi yang jelas dan komponen emosi yang kuat, namun berseberangan dengan Myers (dalam Lopes \& Snyder, 2007) yang menyatakan bahwa masyarakat yang mengalami kemiskinan belum merasakan adanya kebahagian yang ada pada diri mereka sendiri.

Konsep kebahagiaan muncul dari dilema kebahagiaan yang dihadapi oleh individu di area pesisir sebagaimana oleh Frankl (dalam Bastaman, 2000) ada peristiwa hidup yang dijalani. Individuindividu ini hidup dari formasi sosial keluarga petani, nelayan, buruh, dan sebagian kecilnya pegawai. Kehidupan individu-individu ini diwarnai oleh berbagai pengaturan sosial yang mendorong mereka untuk menciptakan konsepsi dasar mengenai kebahagiaan. Konsep kebahagiaan muncul dari ruang semacam ini, di mana setiap individu tidak selalu mengejar keuntungan yang dapat diartikan sebagai ambisi untuk memperoleh kesejahteraan psikologis, melainkan justru dengan mengurangi kehidupan berisiko. Individu-individu ini percaya bahwa hidup "bejo" (beruntung, selamat) dapat dicapai dengan mengurangi faktor-faktor penyebab kemalangan, dan bukan dengan mengejar sebanyak mungkin untung (rezeki wis reti alamate dewe-dewe), serta kepasrahan hidup kepada Tuhan. Dasar argumen semacam inilah yang disebut sebagai dilema kebahagiaan. Bagi individu-individu ini, konsep dasar kebahagiaan bukan dengan menumpuk 
berbagai pengalaman berhasil atau pengalaman sukses melainkan dengan mengurangi pengalaman sedih. Seringkali, pengalaman-pengalaman bahagia masyarakat pesisir cenderung repetitif. Hal ini berarti pengalaman kebahagiaan tidak selalu menjadi dasar dari konsep kebahagiaan ataupun persepsi mengenai kesejahteraan psikologis yang penting untuk diingat.

Kebahagiaan dan kesejahteraan psikologis dapat ditelusuri melalui gagasan pokok, ataupun idiom-idiom yang dapat membantu pemahaman atas konsepkonsep itu sendiri. Riset-riset sebelumnya juga sudah memastikan bahwa idiom dan narasi-narasi kehidupan sehari-hari merupakan ekspresi dinamika psikologis manusia (Williams, Bannister, ArribasAyllon, Preece, dan Spasic, 2015) serta dapat menjadi jalan untuk memahami konsep-konsep kebahagiaan (Suiyerkul \& Chakyroglu, 2014). Urip iku mung mampir ngombe (hidup itu sekadar mampir minum) merupakan salah-satu idiom yang dikenal dalam ajaran filosofi kehidupan. Masyarakat Jawa pada umumnya, terutama yang mempraktikkan ajaran kejawen, sangat dekat dengan idiom urip $i k u$ mung mampir ngombe. "Hidup itu sekadar mampir minum" dalam penelitian ini dimaknai sebagai bentuk ekspresi konsep naratif yang selalu digunakan oleh masyarakat Jawa pesisir sebagai ilustrasi posisi manusia di dunia dan implikasiimplikasinya bagi pembentukan nalar kebahagiaan. Dengan demikian urip iku mung mampir ngombe sebagai bentuk konsep harus ditelusuri sehingga memperoleh pemahaman yang memadai berkenaan dengan konsep-konsep kebahagiaan dan kesejahteraan psikologis masyarakat pesisir.

Fenomena prinsip kebahagiaan masyarakat miskin pesisir di era indus- trialisasi "dekati yang baik-baik, jauhi yang buruk-buruk" menunjukkan bahwa faktor non material dimensi sosial menjadi penting bagi tercapainya human well-being (Helliwell \& Putnam, 2004) dan yang menjelaskan pertumbuhan subjective wellbeing (Bartolini \& Bilancini, 2010). "Dekati yang baik-baik, jauhi yang buruk-buruk" adalah aitem kohesi sosial yang dapat menentukan kepuasan hidup seseorang (Berger-Schmitt \& Regina 2002).

Masyarakat pesisir mencapai konsep kebahagiaan dengan mempertahankan kekerabatan, tukar-menukar rezeki atau hadiah, dan menghindari diri menjadi beban orang lain. Di dalam konsep kebahagiaan, selain argumentasi "dekati yang baik-baik, jauhi yang buruk-buruk" terdapat juga tiga argumentasi lainnya yang akan menjelaskan mengenai kebahagiaan dan kesejahteraan psikologis. Pertama, menjadi bahagia dengan melakukan perbuatan baik (being good doing good). Kedua, menjadi bahagia karena bahagia orang lain. Ketiga, sepi ing pamrih, rame ing gawe. Setiap argumentasi konsep kebahagiaan ini dapat berakar secara normatif dari budaya dan tradisi setempat, atau sebaliknya. Argumentasi-argumentasi ini akan memberikan implikasi dalam praktek kehidupan sehari-hari masyarakat pesisir Yogyakarta.

Implikasi konsep kebahagiaan dalam konteks ekonomi adalah strategi bertahan hidup bahagia dengan berusaha memenuhi kebutuhan hidup sehari-hari. Konsep kebahagiaan menuntun keluargakeluarga miskin di area pesisir Yogyakarta untuk bekerja keras sepanjang hari. Hal ini terjadi pada keluarga-keluarga miskin pesisir yang tidak memiliki lahan garapan sendiri, tidak memiliki tambak garam atau ikan, dan penyewa warung untuk berdagang. Mereka akan bekerja apa saja sehingga kebutuhan untuk makan dan 
minum dapat tercukupi, misalnya dengan membuat jajanan ringan, barang-barang kerajinan, membuat bata, atau berjualan ke pasar. Konsep kebahagiaan bagi keluarga miskin pesisir dari sisi ekonomi menampakkan bukti kuat soal bahagia sebagai sebuah konsekuensi dari hidup subsistent. Terampil dan tidak dalam pekerjaan tidak berpengaruh terhadap kebahagiaan masyarakat pesisir, dan kontradiktif dengan temuan Richard \& Paskov (2016). Kebahagiaan baginya berada pada komponen kepuasan hidup yang memunculkan afek positif dan melahirkan kebahagiaan itu sendiri (Diener, Oishi, \& Lucas, 2002; Schimmack, 2008).

\section{Kesimpulan}

Konsep kebahagiaan menjadi dorongan hidup masyarakat pesisir untuk mencapai kesejahteraan psikologis. Kolektivisme dalam relasi sosial dan budaya dibuktikan memberi pengaruh bagi orang-orang miskin untuk mempertahankan kebahagiaan dan kesejahteraan psikologis, sekalipun dalam batas paling minimum.

Dilema kebahagiaan sebagai bahasan pokok dalam konsep kebahagiaan menunjukkan bagaimana cara masyarakat pesisir Yogyakarta menggambarkan dan merefleksikan kebahagiaan. Bagi masyarakat miskin, konsep kebahagiaan merupakan elemen penting bagi kualitas hidup yang mereka jalani ("laku"). Konsep kebahagiaan merupakan refleksi kontradiktif yang muncul dari dilema kebahagiaan. Petani, nelayan, pedagang, atau buruh di area pesisir Yogyakarta mendasarkan konsep kebahagiaan pada refleksi kontradiktif itu, di mana akumulasi pengalaman kebahagiaan dan pengalaman sedih tidak lebih daripada kenyataan empiris mengenai hakikat "urip" yang mereka sebut dengan "urip mung mampir ngombe". Kebahagiaan dan kesejahteraan psikologis merupakan wujud dari konsekuensi logis hidup subsistent masyarakat miskin di pesisir Yogyakarta.

\section{Saran}

Saran untuk penelitian selanjutnya mengenai konsep kebahagiaan masyarakat pesisir harus mempertimbangkan stigma dan stereotip kemiskinan yang relatif signifikan memengaruhi bentuk ideal konsep kebahagiaan.

\section{Kepustakaan}

Adams, R. E. (1992). Is happiness a home in the suburbs?: The influence of urban versus suburban neighborhoods on psychological health. Journal of Community Psychology, 20(4), 353-372. doi: 10.1002/1520-6629(199210)20:4<35 3::AID-JCOP2290200409>3.0.CO;2-Z

Amato, P. R., \& Zuo, J. (1992). Rural poverty, urban poverty, and psychological well-being. The Sociological Quarterly, 33(2), 229-240. doi: 10.1111/j.1533-85 25.1992.tb00373.x

Balthip, Q., \& Purnell, M. J. (2014). Pursuing meaning and purpose in life among Thai adolescents living with HIV: A grounded theory studi. Journal of the Association of Nurses in AIDS Cara, 25(4), e27-e38. doi: 10.1016/j.jana.2014.03.004.

Bartolini, S., \& Bilancini, E. (2010). If not only GDP, what else? Using relational goods to predict the trends of subjective well-being. International Review of Economy, 57(2), 199-213

Bastaman, H. P. (2000). Logoterapi dan Islam sejalankah dalam metodologi psikologi Islam . Yogyakarta: Kanisius 
Berger-Schmitt, R. (2002). Considering social cohesion in quality of life assessments: Concept and measurement. Social Indicators Research. 58(1), 403-428.

Berry, B. J., \& Okulicz-Kozaryn, A. (2011). An urban-rural happiness gradient. Urban geography, 32(6), 871-883. doi: $\underline{10.2747 / 0272-3638.32 .6 .871}$

Bruscaglioni, L., Cellini, E., \& Saracino, B. (2015). Life on social housing estates: Studying housing quality with an ethnographic approach. In $A$ New Research Agenda for Improvements in Quality of Life (pp. 37-59). Springer, Cham

Casmini. (2016). Kepribadian sehat ala Jawa. Yogyakarta: Kanisius.

Davey, G., Chen, Z., \& Lau, A. (2009). 'Peace in a thatched hut-that is happiness': subjective wellbeing among peasants in rural China. Journal of Happiness Studies, 10(2), 239-252.

Diener, E. D., Oishi, S., \& Lucas, R. E. (2002). Personality, culture, and subjective well-being: Emotional and cognitive evaluations of life, Journal Annual review of psychology, 54(1), 403425, doi: 10.1146/annurev.psych. $\underline{54.101601 .145056}$

Diener, R. B., E. Diener, \& M. Tamir. (2004). The psychology of subjective well being. Daedalus, 133(2), 18-25. doi: $10.1162 / 001152604323049352$

Diener, E., \& Seligman, M. E. P. (2004). Beyond money, toward an economy of well-being. Psychological Science in the Public Interest, 5(1), 1-31. doi: 10.1111/j.0963-7214.2004.00501001.x

Eriksson, M., \& Emmelin, M. (2013). What constitutes a health-enabling neighborhood? A grounded theory situational analysis addressing the significance of social capital and gender. Social Science \& Medicine, 97, 112-123. doi: 10.1016/j.socscimed. 2013.08.008

Freund, M. (1985). Toward a critical theory of happiness: Philoshopical background and methodological significance. New Ideas in Psychology, 3(1), 3-12. doi: 10.1016/0732$\underline{118 \times(85) 90044-3}$

Helliwell, J. F., \& R. D. Putnam. (2004). The social context of well-being. Philosophical transactions: Biological sciences. The science of well-being: Integrating neurobiology. Psychology and Social Science, 359(1449), 14361446.

Kesebir, P., dan E. Diener. (2008). In pursuit of happiness: Empirical answers to philosophical questions. Perspectives on Psychological Science. 3(2), 117-125.

Knight, J., \& Gunatilaka, R. (2010a). Great expectations? the subjective well-being of rural-urban migrants in China. World Development, 38(1), 113-124. doi: $\underline{\text { 10.1016/j.worlddev.2009.03.002 }}$

Knight, J., \& Gunatilaka, R. (2010b). The rural-urban divide in China: Income but not happiness?. The Journal of Development Studies, 46(3), 506-534. doi: $\underline{10.1080 / 00220380903012763}$

Landiyanto, E. A., Ling, M. J., Puspitasari, \& Irianti, S. E., (2011). Wealth and happiness: Empirical evidence from Indonesia. Chulalongkron Journal of Economics. 23(1), 1-17.

Liltsi, P., Michailidis, A., \& Partalidou, M., (2014). Mapping perceived happiness alongside the rural urban continuum. Procedia Economics and Finance, 9, 288 301. doi: 10.1016/S2212-5671(14)00030$\underline{6}$

Lopez, S. J., \& Snyder, C. R. (2007). Positive psychology the scientific and practical 
explorations of human strengths. Kansas: Sage Publication.

Wei, L. \& Gao, F. (2017). Social media, social integration and subjective wellbeing among new urban migrants in China. Telematics and Informatics, 34(3), 786-796, doi: 10.1016/j.tele.2016.05.017

Maggino, F., (2015), Subjective well-being and subjective aspects of well-being: Methodology and theory, Rivista Internazionale di Scienze Sociali, 128(1), 89-121,

https://EconPapers.repec.org/RePEc:ve p:journl:y:2015:v:128:i:1:p:89-121.

Matsunaga, M., Kawamichi, H., Koike, T., Yoshihara, K., Yoshida, Y., Takahashi, H. K., \& Sadato, N. (2016). Structural and functional associations of the rostral anterior cingulate cortex with subjective happiness. NeuroImage, 134, 132-141.

Michalos, A. C. (1983). Satisfaction and happiness in a rural northern resource community. Social Indicators Research, 13(3), 225-252

Panadero, S., Guillén, A. I., Vázquez, J. J. (2015). Happiness on the street: Overall happiness among homeless people in Madrid (Spain). American Journal of Orthopsychiatry, 85(4), 324330.

Paralkar, S., Cloutier, S., Nautiyal, S., \& Mitra, R. (2017). The sustainable neighborhoods for happiness (SNfH) decision tool: Assessing neighborhood level sustainability and happiness. Ecological Indicators, 74(9), 10-18.

Purnamasari, W. D., Setyono, D. A., \& Dayana, I. (2016). Figuring the happiness of poor communities in Malang city: measuring the outcome of slum and squatter areas. ProcediaSocial and Behavioral Sciences, 227, 521529.
Rabahi, M., Yusof, H., \& Awang, M. (2015). Leading learning: A grounded theory perspective of orang asli parental involvement and engagement. Procedia-Social and Behavioral Sciences, 211, 94-103. doi: 10.1016/j.sbspro.2015.11.015.

Ribeiro, L. L. \& Marinho, E. L. L., (2017). Gross national happiness in Brazil: An analysis of its determinants. EconomiA, 18(2), 156-167, doi: 10.1016/j.econ.2016.07.002

Richards, L., \& Paskov, M. (2016). Social class, employment status and inequality in psychological well-being in the UK: Cross-sectional and fixed effects analyses over two decades. Social Science \& Medicine, 167, 45-53. doi: 10.1016/j.socscimed.2016.08.042

Thériault, L., Leclerc, A., Wisniewski, A. E., Chouinard, O., \& Martin, G. (2010). "Not just an apartment building": residents' quality of life in a social housing co-operative. Canadian Journal of Nonprofit and Social Economy Research, 1(1), 82.

Schimmack, U. (2008). The structure of subjective well-being. In M. Eid \& R. J. Larsen (Eds.), The science of subjective well-being. 97-123. New York, NY, US: Guilford Press.

Seligman, M. (2002). Authentic happiness: Using the new positive psychology to realize your potential for lasting fulfillment. New York: Free Press.

Sohn, K. (2010). Considering happiness for economic development: Determinants of happiness in Indonesia. KIEP Working Paper. 10(9), 1-61. doi: 10.2139/ssrn.2489785

Stets, J. E. \& Trettvik, R. (2016). Happiness and identities. Social Science Research, 58, 1-13, doi: 10.1016/j.ssresearch. 2016.04.011 
Suiyerkul, B., \& Chakyroglu, A. K. (2014). Representation of the concepts "happiness \& unhappiness" in the Kazakh proverbs and sayings. Procedia-Social and Behavioral Sciences, 136, 129-132. doi: 10.1016/j.sbspro. $\underline{2014.05 .302}$

Williams, L., Bannister, C., Arribas-Ayllon, M., Preece, A., \& Spasić, I. (2015). The role of idioms in sentiment analysis. Expert Systems with Applications, 42(21), 7375-7385. doi: 10.1016/j.eswa. 2015. $\underline{05.039}$

White, N. P. (2006). A brief history of happiness. New York: Blackwell Publishing. 